\title{
Actions of vasoactive intestinal peptide on the rat adrenal zona glomerulosa
}

\author{
J P Hinson, J R Puddefoot and S Kapas ${ }^{1}$ \\ Molecular and Cellular Biology Section, Division of Biomedical Sciences, St Bartholomew's and The Royal London School of Medicine and Dentistry, \\ Queen Mary and Westfield College, Mile End Road, London E1 4NS, UK \\ ${ }^{1}$ Oral Diseases Research Centre, St Bartholomew's and The Royal London School of Medicine and Dentistry, 2 Newark Street, London E1 2AT, UK \\ (Requests for offprints should be addressed to J P Hinson)
}

\begin{abstract}
Previous studies, by this group and others, have shown that vasoactive intestinal peptide (VIP) stimulates aldosterone secretion, and that the actions of VIP on aldosterone secretion by the rat adrenal cortex are blocked by $\beta$ adrenergic antagonists, suggesting that VIP may act by the local release of catecholamines. The present studies were designed to test this hypothesis further, by measuring catecholamine release by adrenal capsular tissue in response to VIP stimulation.

Using intact capsular tissue it was found that VIP caused a dose-dependent increase in aldosterone secretion, with a concomitant increase in both adrenaline and noradrenaline release. The effects of VIP on aldosterone secretion were inhibited by atenolol, a $\beta_{1}$ adrenergic antagonist, but not by ICI-118,551, a $\beta_{2}$ adrenergic antagonist. Binding studies were carried out to investigate VIP receptors. It was found that adrenal zona glomerulosa tissue from control rats contained specific VIP binding sites $\left(\mathrm{B}_{\max }\right.$ $853 \pm 101 \mathrm{fmol} / \mathrm{mg}$ protein; $\left.K_{\mathrm{d}} 2 \cdot 26 \pm 0 \cdot 45 \mathrm{nmol} / \mathrm{l}\right)$. VIP binding was not displaced by ACTH, angiotensin II or by either of the $\beta$ adrenergic antagonists.
\end{abstract}

The response to VIP in adrenals obtained from rats fed a low sodium diet was also investigated. Previous studies have found that adrenals from animals on a low sodium diet exhibit increased responsiveness to VIP. Specific VIP binding sites were identified, although the concentration or affinity of binding sites in the low sodium group was not significantly different from the controls. In the low sodium group VIP was found to increase catecholamine release to the same extent as in the control group, however, in contrast to the control group, the adrenal response to VIP was not altered by adrenergic antagonists in the low sodium group.

These data provide strong support for the hypothesis that VIP acts by the local release of catecholamines in adrenal zona glomerulosa tissue in normal animals. It does not appear that VIP acts through the same mechanism in animals maintained on a low sodium diet. The mechanism by which VIP stimulates aldosterone in this group remains to be determined.

Journal of Endocrinology (1999) 161, 51-57

\section{Introduction}

A range of neuropeptides is present in the rat adrenal cortex (for review see Vinson et al. 1994, Toth \& Hinson 1995, Nussdorfer 1996, Ehrhart-Bornstein et al. 1998). Of these peptides vasoactive intestinal peptide (VIP) has been the most extensively studied. VIP has been shown to be present in nerves supplying the capsule and zona glomerulosa region of the adrenal gland (Hökfelt et al. 1981, Holzwarth 1984) and has been shown to exert a significant influence on zona glomerulosa function. Prolonged infusion of VIP stimulates the growth and secretory capacity of the zona glomerulosa of rats and infusion of a VIP antagonist suppresses zona glomerulosa growth and secretory capacity (Rebuffat et al. 1994). Experiments in vitro have given different results, depending on the tissue preparation used: it has been shown that VIP stimulates aldosterone secretion by rat adrenal capsular tissue (Cunningham \& Holzwarth 1988) and by the intact perfused rat adrenal gland (Hinson et al. 1992, 1994). However, experiments investigating the actions of VIP using dispersed zona glomerulosa cells from normal rats failed to demonstrate stimulation of aldosterone secretion (Enyedi et al. 1983, Hinson et al. 1992).

In 1992 we proposed an hypothesis to account for the differences in responsiveness of the different adrenal preparations (Hinson et al. 1992). We proposed that VIP acts on islets of chromaffin cells, known to be present in the zona glomerulosa in the rat (Kovács \& Horváth 1973, Palacios \& Lafraga 1975, Gallo-Payet et al. 1987) and other species (for review see Nussdorfer 1996), to stimulate the release of catecholamines, which then act on adrenal cells to stimulate aldosterone secretion. This hypothesis was supported by the observation that aldosterone secretion in 
response to VIP was attenuated in the presence of alprenolol, a $\beta$ adrenergic antagonist (Hinson et al. 1992). Similar observations have subsequently been made by other groups (Mazzocchi et al. 1993, Bernet et al. 1994), but to date no evidence has been presented to show a relationship between catecholamine release and aldosterone secretion. In addition, the possibility that $\beta$ adrenergic antagonists might alter VIP binding to its receptor has not been investigated.

The present studies were designed to investigate the actions of VIP and catecholamines on zona glomerulosa function. These studies have employed both normal rats, and rats fed a low sodium diet, as there is evidence that the adrenal response to VIP is altered following dietary sodium depletion (Hinson \& Kapas 1995). We have investigated the effects of VIP on catecholamine release by adrenal capsular tissue, and we have used ligand binding studies to investigate the specificity of VIP binding to the zona glomerulosa.

\section{Materials and Methods}

\section{Materials}

VIP and the VIP receptor antagonist, [4-Cl-D$\mathrm{Phe}^{6}, \mathrm{Leu}^{17}$ ]-VIP (PL-VIP) were obtained from Bachem (UK) Ltd, Saffron Walden, Essex, UK; ICI 118551 (( \pm )-1-[2,3-(dihydro-7-methyl-iH-inden-4-yl)oxyl]-3[1-methylethyl)amino]-2-butanol hydrochloride) was from Semat Technical (UK) Ltd, St Albans, Herts, UK; collagenase (Worthington type I) from Lorne Laboratories Ltd, Reading, Berks, UK. All radiolabels were obtained from Amersham International plc, Amersham, Bucks, UK. All other chemicals were of analytical grade obtained from Sigma Chemical Co., Poole, Dorset, UK or BDH, Dagenham, Essex, UK.

\section{Sodium depletion of animals}

Male and female Wistar rats (250-400 g body weight), supplied by A Tuck \& Sons, Battlesbridge, Essex, UK and maintained at Queen Mary and Westfield College, were used. Animals were depleted of sodium, as previously described (Fattah et al. 1978) by feeding them a diet of wholemeal flour supplemented with $100 \mathrm{nmol}$ calcium carbonate $/ \mathrm{kg}$ for a minimum period of 21 days, with access to distilled water. Control animals were fed the same diet with the addition of $170 \mathrm{mmol}$ sodium chloride/ $\mathrm{kg}$. These experiments were authorised by Home Office project licence number 70/00063.

\section{Preparation of rat adrenal capsules}

The rats were stunned and then killed by cervical dislocation. Adrenals were rapidly removed and cleaned of adhering fat. Capsule fractions (with mainly glomerulosa cells attached) were separated from inner adrenocortical tissue by pressure between glass plates. Capsules were preincubated in Krebs bicarbonate Ringer containing glucose $(200 \mathrm{mg} / 100 \mathrm{ml})(\mathrm{KRBG})$ for $1 \mathrm{~h}$ at $37^{\circ} \mathrm{C}$ under an atmosphere of $95 \% \mathrm{O}_{2}$ and $5 \% \mathrm{CO}_{2}$. After preincubation capsules were incubated in fresh KRBG for $1 \mathrm{~h}$ under an atmosphere of $95 \% \mathrm{O}_{2}$ and $5 \% \mathrm{CO}_{2}$ in the absence or presence of stimulants \pm inhibitors.

\section{Effect of agonists \pm inhibitors on steroidogenesis}

All peptides were dissolved in KRBG to the required concentrations. A range of concentrations of VIP, from $10^{-10} \mathrm{~mol} / 1$ to $10^{-6} \mathrm{~mol} / \mathrm{l}$ were used. In other experiments, to test the action of antagonists on VIP-stimulated aldosterone secretion, capsules were incubated with various concentrations of VIP in the presence of $10^{-7} \mathrm{~mol} / 1$ antagonist for $1 \mathrm{~h}$. After incubation, the capsules were discarded and half the incubation media were placed into clean microfuge tubes and the tubes stored at $-20{ }^{\circ} \mathrm{C}$ until the media were assayed for aldosterone. Aldosterone was measured in an aliquot of unextracted incubation medium by direct radioimmunoassay (RIA; Kapas et al. 1992). A small volume of acetic acid was added to the remaining incubation media (final concentration 10\%, $\mathrm{v} / \mathrm{v}$ ) and the media assayed for catecholamines.

\section{Catecholamine assay}

The assay of adrenaline and noradrenaline is based on the trihydroxyindole fluorescence method of Brocklehurst \& Pollard (1990). The technique involves the oxidation of catecholamines by $\mathrm{K}_{2} \mathrm{Fe}(\mathrm{CN})_{6}$ and the subsequent generation of the trihydroxyindole fluorophore product by $\mathrm{NaOH}$ and ascorbic acid. The oxidation reactions are performed under both acidic and neutral $\mathrm{pH}$ conditions to allow measurement of adrenaline and noradrenaline. Briefly, assays were carried out as follows. To one set of $50 \mu \mathrm{l}$ samples $500 \mu \mathrm{l} 0.5 \mathrm{~mol} / 1$ sodium phosphate buffer $(\mathrm{pH} 7 \cdot 0)$ were added. To another (identical) set of samples $500 \mu \mathrm{l} 10 \%$ (v/v) acetic acid were added. All samples received $50 \mu \mathrm{K}_{2} \mathrm{Fe}(\mathrm{CN})_{6}$ and were incubated on ice for $20 \mathrm{~min}$. The reactions were terminated with $1 \mathrm{ml} 9 \mathrm{~mol} / 1$ $\mathrm{NaOH}$ containing $0 \cdot 4 \%$ ascorbic acid $(\mathrm{w} / \mathrm{v})$, followed by vigorous vortexing. After the addition of $2 \mathrm{ml}$ water, the trihydroxyindole fluorescence product was measured in a spectrofluorimeter (Luminescent fluorimeter LS-50B, Perkin Elmer, Warrington, Lancs, UK) with an excitation wavelength of $412 \mathrm{~nm}$ and an emission wavelength of $523 \mathrm{~nm}$.

\section{Receptor binding assay}

The binding assay was carried out as previously described (Kapas et al. 1996). Rat adrenal capsules were prepared as 
described above. After incubation, capsules were homogenised in $150 \mathrm{mmol} / \mathrm{l}$ Tris- $\mathrm{HCl}$ buffer $(\mathrm{pH} 7 \cdot 6$ ) containing $1 \mu \mathrm{g} / \mathrm{ml}$ each of aprotinin and soybean trypsin inhibitor. Homogenates were centrifuged at $800 \boldsymbol{g}$ for $10 \mathrm{~min}$ and the supernatant re-centrifuged at $100000 \boldsymbol{g}$ for $1 \mathrm{~h}$. The particulate (membrane) fraction was then resuspended in Tris- $\mathrm{HCl}$ buffer containing $100 \mathrm{mmol} / \mathrm{l}$ $\mathrm{NaCl}, 6 \mathrm{mmol} / 1 \mathrm{MgCl}_{2}, 0 \cdot 1 \%(\mathrm{w} / \mathrm{v}) \mathrm{BSA}$ and protease inhibitors $(1 \mathrm{ug} / \mathrm{ml}$ each of soybean trypsin inhibitor and aprotinin).

Aliquots of membrane suspension (100 $\mu \mathrm{g}$ protein/tube) were incubated with $3-\left({ }^{125}\right.$ I-iodotyrosyl $\left.{ }^{10}\right)$ VIP $(2000 \mathrm{Ci}$ / $\mathrm{mmol}$; final concentration $0 \cdot 1 \mathrm{nmol} / \mathrm{l})$ with increasing concentrations of unlabelled VIP, PL-VIP, atenolol, ICI 118 551, angiotensin II and adrenocorticotrophic hormone (ACTH) $(0 \cdot 39-50 \mathrm{nmol} / \mathrm{l})$. Non-specific binding was determined by incubating labelled cells with 100-fold excess of unlabelled VIP. Incubations were terminated by the addition of $800 \mu \mathrm{l}$ ice-cold buffer and the tubes were centrifuged at $10000 \mathrm{~g}$ for $5 \mathrm{~min}$ at $4{ }^{\circ} \mathrm{C}$. Supernatants were discarded and the pellets washed twice. After washing, radioactivity bound to the membrane was estimated using a 1272 Clinigamma counter (LKB Wallac, St Albans, Herts, UK). Binding studies were repeated at least three times.

\section{Statistical analysis}

Arithmetic means and S.E.M. values were calculated. One-way analysis of variance was used to test whether VIP had a significant effect on basal (control) levels of aldosterone or catecholamine release as appropriate. Student's $t$-tests were used to test whether the abovementioned responses were affected by the presence of antagonists. Saturation data were analysed by LIGAND (Munson \& Rodbard 1980). Student's t-tests were also used to test whether the responses of the sodium-depleted group were significantly different to those of the control diet group.

\section{Results}

VIP was found to cause a dose-dependent increase in both aldosterone and catecholamine secretion by rat adrenal capsular tissue in vitro (Fig. 1). Release of both adrenaline and noradrenaline was observed, with the increase in adrenaline seen in parallel with aldosterone secretion. The minimum concentration of VIP required for significant stimulation of aldosterone and adrenaline was $1 \mathrm{nmol} / \mathrm{l}$, although $10 \mathrm{nmol} / 1$ were required for significant noradrenaline secretion. The effects of VIP on aldosterone secretion were inhibited by the $\beta_{1}$ antagonist, atenolol (100 nmol/l), but not by ICI 118 551, a $\beta_{2}$ antagonist (Fig. 2 ). The effects of VIP were totally specific to the zona glomerulosa: there was no effect of VIP on corticosterone release by inner zone tissue (data not shown).

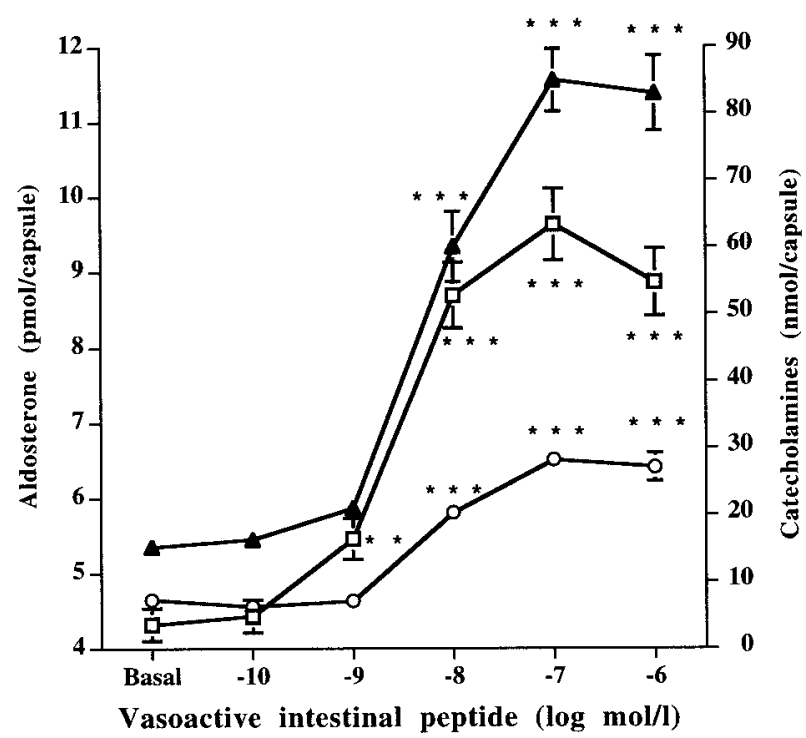

Figure 1 Effects of increasing concentrations of VIP on aldosterone secretion $(\triangle)$, adrenaline $(\square)$ and noradrenaline $(\bigcirc)$ release by rat adrenal capsules. Values are means \pm S.E.M.. $(n=6)$. ${ }^{*} P<0 \cdot 01,{ }^{* *} P<0 \cdot 001$ (analysis of variance).

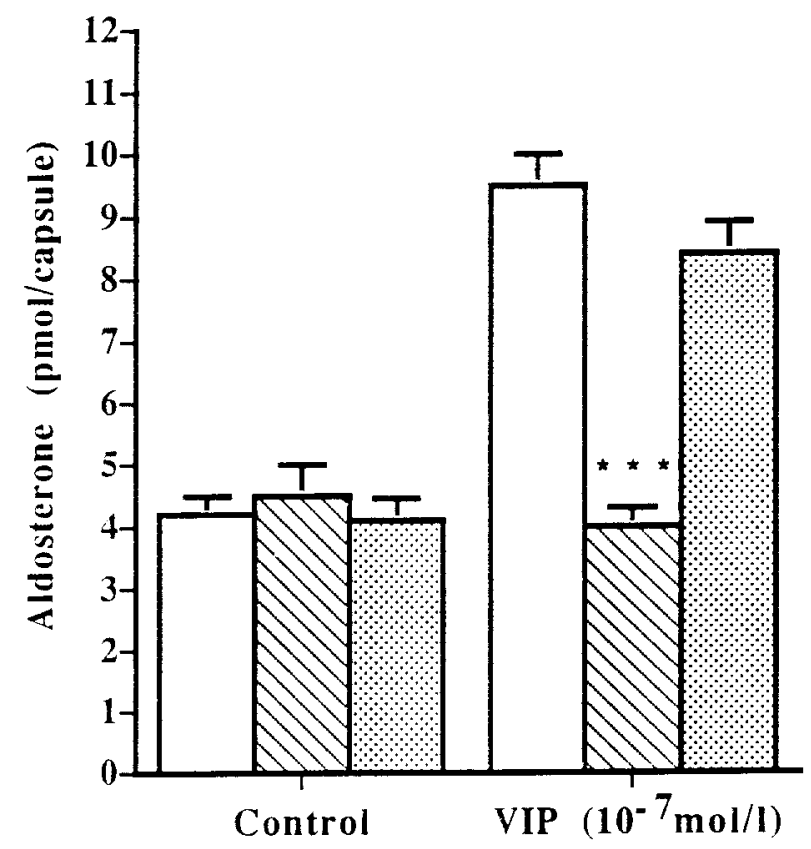

Figure 2 Effects of atenolol (100 nmol/l; hatched bars), a $\beta_{1}$ adrenergic antagonist, and ICI $118551(100 \mathrm{nmol} / \mathrm{l}$; speckled bars), a $\beta_{2}$ adrenergic antagonist, on the aldosterone response to VIP (100 nmol/l) stimulation. Open bars, absence of inhibitor. Values are means \pm S.E.M. $(n=6) .{ }^{* *} P<0 \cdot 001$ (analysis of variance).

Ligand binding studies revealed a single population of VIP receptors in both control and the low sodium animals (Fig. 3). The Hill coefficient for the control group was 0.908 , and for the low sodium group 0.925. The VIP 

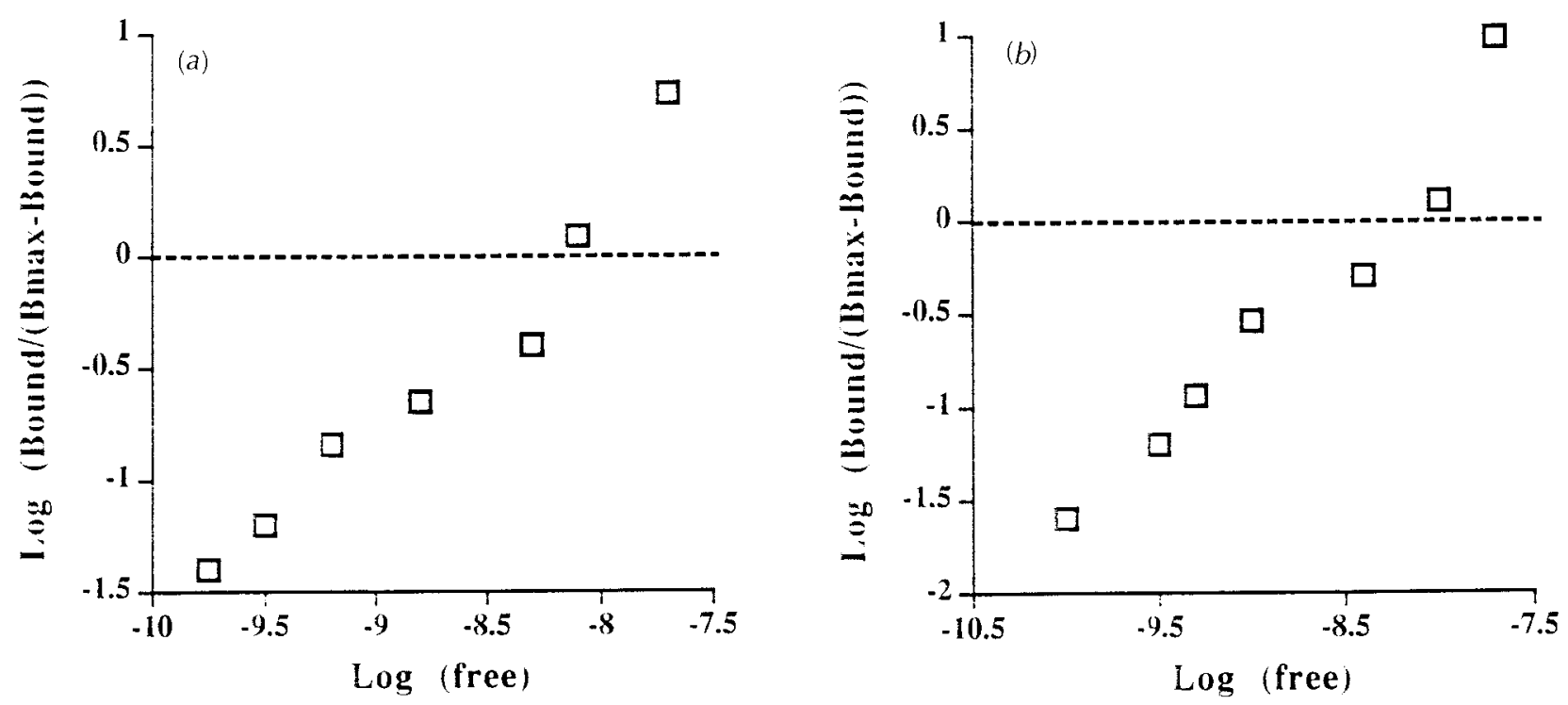

Figure 3 Hill plot of VIP binding to adrenal capsular homogenates from (a) control animals and (b) animals maintained on a low sodium diet.

receptors from both groups were found to have a similar $K_{\mathrm{d}}: 2 \cdot 26 \pm 0 \cdot 45 \mathrm{nmol} / 1$ in the control group and $1 \cdot 62 \pm$ $0 \cdot 32 \mathrm{nmol} / 1$ in the low sodium group. While the low sodium group had a higher number of binding sites than the controls (944 \pm 153 vs $853 \pm 101 \mathrm{fmol} / \mathrm{mg}$ protein), this difference was not statistically significant. Displacement studies showed that VIP binding to homogenates of adrenal capsules from the control or low sodium group was not significantly displaced by ACTH, angiotensin II, atenolol or ICI 118551 (Table 1).

In adrenal capsular tissue obtained from sodiumdepleted animals VIP significantly stimulated aldosterone secretion (Fig. 4). The basal level of aldosterone secretion was considerably greater in the sodium-depleted adrenals compared with the controls. In the capsules from sodiumdepleted animals VIP also significantly stimulated the release of adrenaline and noradrenaline (Fig. 5). There

Table 1 Effects of various agents $(50 \mu \mathrm{mol} / \mathrm{l})$ on displacement of ${ }^{125}$ I-labelled VIP binding to capsular homogenates from control rats and from rats maintained on a low sodium diet

\begin{tabular}{|c|c|c|}
\hline \multirow[b]{3}{*}{ Agent } & \multicolumn{2}{|c|}{${ }^{125}$ I-VIP displaced } \\
\hline & Controls & Low sodium \\
\hline & & \\
\hline VIP & $100 \pm 15 \cdot 0^{* \star *}$ & $100 \pm 10 \cdot 0^{* * *}$ \\
\hline PL-VIP & $95 \pm 7 \cdot 0^{* * *}$ & $97 \pm 10 \cdot 0^{* * *}$ \\
\hline АCTH & $2 \pm 0 \cdot 4$ & $3 \pm 0 \cdot 8$ \\
\hline Angiotensin II & $1 \pm 0 \cdot 3$ & $3 \pm 1 \cdot 0$ \\
\hline Atenolol & $5 \pm 0 \cdot 8$ & $4 \pm 1 \cdot 0$ \\
\hline ICI 118551 & $3 \pm 1 \cdot 0$ & $3 \pm 0 \cdot 6$ \\
\hline
\end{tabular}

${ }^{* * *} P<0 \cdot 001$ (analysis of variance) compared with control. were no significant differences between levels of catecholamine release, either basal or stimulated, in the sodiumdepleted group compared with the controls. However, in the sodium-depleted adrenal capsules the aldosterone response to VIP stimulation was not attenuated by atenolol (Fig. 4).

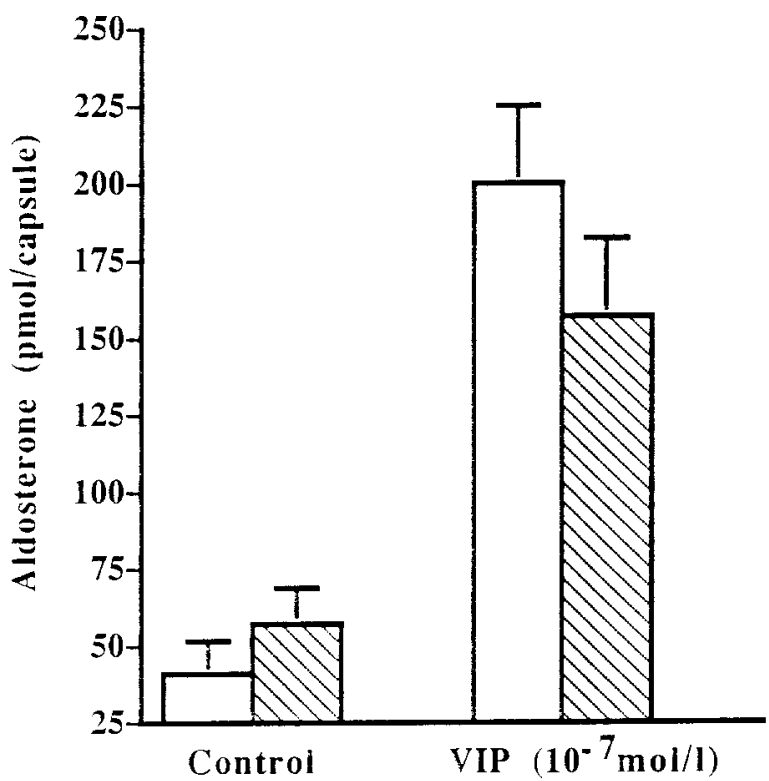

Figure 4 The $\beta_{1}$ adrenergic antagonist, atenolol $(100 \mathrm{nmol} / \mathrm{l}$ : hatched bars), had no effect on the aldosterone response to VIP $(100 \mathrm{nmol} / \mathrm{l})$ in adrenals obtained from animals maintained on a low sodium diet. Values are means \pm S.E.M. $(n=6)$. 

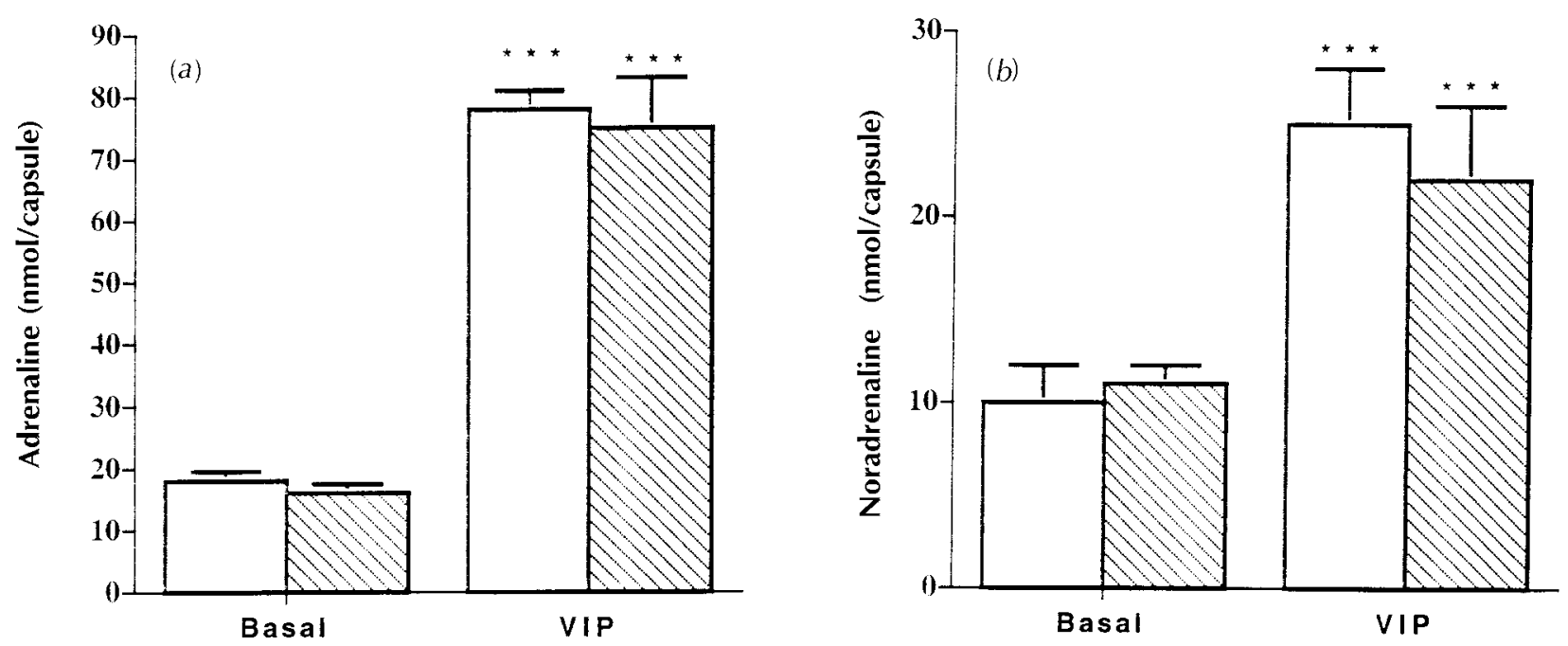

Figure 5 Effect of VIP (100 nmol/l) on (a) adrenaline and (b) noradrenaline release by adrenal capsules from control animals (open bars) and animals maintained on a low sodium diet (hatched bars). Values are means \pm S.E.M. $(n=6) .{ }^{* *} P<0 \cdot 001$, compared with appropriate control.

\section{Discussion}

The results presented clearly demonstrate that VIP had a dose-dependent effect on the release of catecholamines from adrenal capsular tissue. The release of adrenaline, but not noradrenaline, was found to parallel the increase in aldosterone secretion. The ratio of adrenaline/ noradrenaline found in this study is consistent with that previously reported in rat adrenal capsules and in the rat adrenal medulla (Pratt et al. 1985). Presumably the catecholamines are derived from the islets of chromaffin cells reported to be present in the zona glomerulosa region of the adrenal cortex (Kovács \& Horváth 1973, Palacios \& Lafraga 1975, Gallo-Payet et al. 1987), as the adrenal capsules were separated from the adrenal medulla in these experiments. It is, however, possible that noradrenaline may be released from nerve terminals remaining in the separated capsular tissue. It is well established that VIP stimulates catecholamine release from adrenal medullary chromaffin cells (Malhotra \& Wakade 1987, Wakade et al. 1991). In this study it was found that the release of adrenaline in response to VIP displayed the same doseresponse characteristics, supporting the contention that local catecholamine release mediates the response to VIP in this tissue.

Most previous studies, investigating the possible role of catecholamines in the aldosterone response to VIP stimulation, have failed to demonstrate release of catecholamines in response to VIP, although we have published some preliminary data (Hinson et al. 1992, 1996). Instead, most attention has been focussed on the effects of $\beta$ adrenergic antagonists, specifically alprenolol and propranolol, nonselective $\beta$ adrenergic antagonists, and atenolol, a selective $\beta_{1}$ antagonist. These agents have been found to signifi- cantly inhibit the response of the zona glomerulosa of both rat and human adrenals to VIP stimulation (Mazzocchi et al. 1993, Bernet et al. 1994, Bornstein et al. 1996). In the absence of data on either catecholamine release, or on VIP binding, the mechanism of action of these agents has remained speculative. As previous studies have shown that neuropeptide $\mathrm{Y}$ interacts with $\alpha$ adrenoceptors (Martire \& Pistritto 1992), this appeared to be a possible mechanism of the inhibitory action of $\beta$ adrenergic antagonists on VIP stimulation of aldosterone secretion. The data obtained in the present study, however, clearly demonstrating release of catecholamines in response to VIP, together with the observed specificity of the VIP binding, supports the hypothesis that $\beta$ adrenergic antagonists inhibit the aldosterone response to VIP by blocking the action of catecholamines released in response to VIP stimulation.

The question as to whether the catecholamines are able to influence aldosterone secretion was not directly addressed by the present study, as there is already much evidence to support the contention that $\beta$ adrenergic agonists stimulate aldosterone secretion in a variety of different rat adrenal preparations, including adrenal slices (Andreis et al. 1995), capsular preparations in vitro (Shima et al. 1984, Pratt et al. 1985, Pratt \& McAteer 1989), the isolated perfused adrenal preparation (J P Hinson, unpublished observations) and dispersed zona glomerulosa cell preparations (Horiuchi et al. 1987). The question of the physiological role of the VIP-catecholamine system in the regulation of zona glomerulosa function remains unclear.

It has been suggested that the effects of VIP in the adrenal gland are mediated in part via the ACTH receptor (Li et al. 1990, Mazzocchi et al. 1994). This suggestion was originally made following the observation that VIP displaced binding of labelled ACTH from a subpopulation of 
ACTH receptors ( $\mathrm{Li}$ et al. 1990) and was restated on the basis that corticotrophin inhibitory peptide was shown to attenuate the rat adrenal response to VIP stimulation (Mazzocchi et al. 1994). Data from the present studies do not support this contention: a single population of VIP binding sites was identified in the zona glomerulosa, and only VIP and its specific antagonist (PL-VIP) were found to displace binding of labelled VIP. Neither ACTH, angiotensin II nor the $\beta$ adrenergic antagonists were found to displace labelled VIP, suggesting that the zona glomerulosa expresses a single population of VIP receptors. We have not investigated the possibility that ACTH may interact with the specific VIP receptors identified in the adrenal cortex, although this possibility may partly explain the observations of Li and coworkers (1990). This study did not address the question as to which of the VIP receptor subtypes (for review see Harmar et al. 1998) are present in the rat zona glomerulosa and mediate the actions of VIP in this tissue, but the binding studies suggest that only one receptor subtype is present.

We have previously observed an increase in adrenal VIP content in animals maintained on a low sodium diet, raising the possibility that locally produced VIP has a role in the adrenal response to perturbed electrolyte balance (Hinson et al. 1996). We also reported an increase in the adrenal responsiveness to VIP following dietary sodium depletion, such that aldosterone secretion was significantly stimulated by a lower concentration of VIP in the low sodium group compared with controls (Hinson \& Kapas 1995), and proposed that the zona glomerulosa expresses a distinct population of VIP receptors in response to changes in electrolyte balance. The results of the present study do not support this proposal: it was found that adrenals from the low sodium group of animals expressed a population of VIP receptors with the same $K_{\mathrm{d}}$ as controls, and with only a marginally greater $B_{\max }$, which was not significantly different from controls.

One of the most interesting observations made in the present study was that the aldosterone response of adrenals from the low sodium group was not attenuated by the $\beta$ adrenergic antagonist, atenolol, although catecholamine release was elevated by VIP to the same extent as in the control group. It is not clear why atenolol had no effect in this group, although it is possible that a different subtype of adrenergic receptor is expressed in the adrenals of animals maintained on a low sodium diet. However, the data obtained in the present study suggest that it is not the $\beta_{2}$ subtype of adrenoceptor and other studies have found that activation of $\alpha$ adrenoceptors in the rat adrenal cortex inhibits aldosterone secretion (Lotshaw et al. 1991) so this is most unlikely to be the mechanism by which VIP exerts its stimulatory effects in this group. Clearly this requires further study.

In conclusion, these data suggest that VIP stimulates aldosterone secretion indirectly via release of catecholamines. There appear to be different mechanisms medi- ating the actions of VIP in animals fed a low sodium diet compared with controls, but the nature of these mechanisms is not yet clear. The physiological significance of a VIP-catecholamine system in the regulation of aldosterone secretion also remains unclear.

\section{Acknowledgements}

We are most grateful to the Wellcome Trust for project grant support.

\section{References}

Andreis PG, Malendowicz LK, Belloni AS \& Nussdorfer GG 1995 Effects of pituitary adenylate cyclase-activating peptide (PACAP) on the rat adrenal secretory activity: preliminary in vitro studies. Life Sciences 56 135-142.

Bernet F, Bernard J, Laborie C, Montel V, Maubert E \& Dupouy JP 1994 Neuropeptide Y (NPY)- and vasoactive intestinal peptide (VIP)-induced aldosterone secretion by rat capsule/glomerular zone could be mediated by catecholamines via $\beta_{1}$ adrenergic receptors. Neuroscience Letters 166 109-112.

Bornstein SR, Haidan A \& Ehrhart-Bornstein M 1996 Cellular communication in the neuroadrenocortical axis: role of vasoactive intestinal polypeptide (VIP). Endocrine Research 22 819-829.

Brocklehurst KW \& Pollard HB 1990 Cell biology of secretion. In Peptide Hormone Secretion: A Practical Approach, pp 235-238. Eds JC Hutton \& K Siddle. Oxford: IRL Press.

Cunningham LA \& Holzwarth MA 1988 Vasoactive intestinal peptide stimulates adrenal aldosterone and corticosterone secretion. Endocrinology 122 2090-2097.

Ehrhart-Bornstein M, Hinson JP, Bornstein S, Scherbaum WA \& Vinson GP 1998 Intraadrenal interactions in the regulation of adrenocortical steroidogenesis. Endocrine Reviews 19 101-143.

Enyedi P, Szabo B \& Spät A 1983 Failure of vasoactive intestinal peptide to stimulate aldosterone production. Acta Physiologica Hungarica 61 77-79.

Fattah DI, Whitehouse BJ \& Vinson GP 1978 Biosynthesis of aldosterone from 18-hydroxylated precursors by rat adrenal tissue in vitro. Journal of Endocrinology 75 187-195.

Gallo-Payet N, Pothier P \& Isler H 1987 On the presence of chromaffin cells in the adrenal cortex: their possible role in adrenocortical function. Biochemistry and Cell Biology 65 588-592.

Harmar AJ, Arimura A, Gozes I, Journot L, Laburthe M, Pisegna JR, Rawlings SR, Robberecht P, Said SI, Sreedharan SP, Wank SA \& Waschek JA 1998 International Union of Pharmacology. XVIII. Nomenclature of receptors for vasoactive intestinal peptide and pituitary adenylyl cyclase-activating polypeptide. Pharmacological Reviews $\mathbf{5 0}$ 265-270.

Hinson JP \& Kapas S 1995 Effects of sodium depletion on the response of rat adrenal zona glomerulosa cells to stimulation by neuropeptides: actions of vasoactive intestinal peptide, enkephalin, substance $\mathrm{P}$, neuropeptide $\mathrm{Y}$ and corticotrophin releasing hormone. Journal of Endocrinology 146 209-214.

Hinson JP, Kapas S, Orford CD \& Vinson GP 1992 Vasoactive intestinal peptide stimulation of aldosterone secretion may be mediated by the local release of catecholamines. Journal of Endocrinology 133 253-258.

Hinson JP, Cameron LA, Purbrick A \& Kapas S 1994 The role of neuropeptides in the regulation of adrenal zona glomerulosa function: effects of substance $\mathrm{P}$, neuropeptide $\mathrm{Y}$, neurotensin, metenkephalin, leu-enkephalin and corticotrophin-releasing hormone on aldosterone secretion in the intact perfused rat adrenal. Journal of Endocrinology 140 91-96. 
Hinson JP, Ho MM, Vinson GP \& Kapas S 1996 Vasoactive intestinal peptide is a local regulator of adrenocortical function. Endocrine Research 22 831-838.

Hökfelt T, Lundberg JM, Schulzberg M \& Fahrenkrug J 1981 Immunohistochemical evidence for a local VIP-ergic neuron system in the adrenal gland of the rat. Acta Physiologica Scandinavica 113 575-576.

Holzwarth MA 1984 The distribution of vasoactive intestinal peptide in the rat adrenal cortex and medulla. Journal of the Autonomic Nervous System 11 269-283.

Horiuchi T, Tanaka K \& Shimizu N 1987 Effect of catecholamine on aldosterone release in isolated rat glomerulosa cell suspensions. Life Sciences 40 2421-2428.

Kapas S, Orford CD, Barker S, Vinson GP \& Hinson JP 1992 Studies on the intracellular mechanism of action of $\alpha$-melanocytestimulating hormone on rat adrenal zona glomerulosa. Journal of Molecular Endocrinology 9 47-54.

Kapas S, Cameron LA, Puddefoot JR \& Hinson JP 1996 Studies on endothelin receptors in the zona fasciculata/reticularis of the rat adrenal cortex: contrast with the zona glomerulosa. FEBS Letters 397 186-190.

Kovács K \& Horváth E 1973 Corticomedullary cells in a human adrenal cortical adenoma and in rat adrenal cortex. Anatomischer Anzeiger 134 387-389.

Li ZG, Queen G \& LaBella FS 1990 Adrenocorticotropin, vasoactive intestinal polypeptide, growth hormone releasing factor and dynorphin compete for common receptors in brain and adrenal. Endocrinology 126 1327-1333.

Lotshaw DP, Franco-Saenz R \& Mulrow PJ 1991 Guanobenzinduced inhibition of aldosterone secretion from isolated rat adrenal glomerulosa cells. American Journal of Medical Science 301 15-20.

Malhotra RK \& Wakade AR 1987 Vasoactive intestinal polypeptide stimulates the secretion of catecholamines from the rat adrenal gland. Journal of Physiology 388 285-294.

Martire M \& Pistritto G 1992 Neuropeptide Y interaction with the adrenergic transmission line - a study of its effects on alpha 2 adrenergic receptors. Pharmacological Research 25 203-215.

Mazzocchi G, Malendowicz LK, Meneghelli V, Gottardo G \& Nussdorfer GG 1993 Vasoactive intestinal polypeptide (VIP) stimulates hormonal secretion of the rat adrenal cortex in vitro: evidence that adrenal chromaffin cells are involved in the mediation of the mineralocorticoid, but not glucocorticoid secretagogue action of VIP. Biomedical Research 14 435-440.
Mazzocchi G, Malendowicz LK \& Nussdorfer GG 1994 Stimulatory effect of vasoactive intestinal peptide (VIP) on the secretory activity of dispersed rat adrenocortical cells. Evidence for the interaction of VIP with ACTH receptors. Journal of Steroid Biochemistry and Molecular Biology 48 507-510.

Munson PJ \& Rodbard D 1980 LIGAND: a versatile computerized approach for characterization of ligand-binding systems. Analytical Biochemistry 107 220-230.

Nussdorfer GG 1996 Paracrine control of adrenal cortical function by medullary chromaffin cells. Pharmacological Reviews 48 495-530.

Palacios G \& Lafraga M 1975 Chromaffin cells in the glomerular zone of adult rat adrenal cortex. Cell and Tissue Research 164 275-278.

Pratt JH \& McAteer JA 1989 Beta-adrenergic enhancement of angiotensin II-stimulated aldosterone secretion. Life Sciences $\mathbf{4 4}$ 2089-2095.

Pratt JH, Turner DA, McAteer JA \& Henry DP 1985 ß-Adrenergic stimulation of aldosterone production by rat adrenal capsular explants. Endocrinology 117 1189-1194.

Rebuffat P, Nowak KW, Tortorella C, Musajo FG, Gottardo G, Mazzocchi G \& Nussdorfer GG 1994 Evidence that endogenous vasoactive intestinal polypeptide plays a role in the maintenance of the growth and steroidogenic capacity of rat adrenal zona glomerulosa. Journal of Steroid Biochemistry and Molecular Biology 51 81-88.

Shima S, Komoriyama K, Hirai M \& Kouyama H 1984 Studies on cyclic nucleotides on the adrenal gland. XI. Adrenergic regulation of adenylate cyclase activity in the adrenal cortex. Endocrinology 114 325-329.

Toth IE \& Hinson JP 1995 Neuropeptides in the adrenal gland: distribution, localisation of receptors and effects on steroid hormone synthesis. Endocrine Research 21 39-51.

Vinson GP, Hinson JP \& Toth IE 1994 The neuroendocrinology of the adrenal cortex. Journal of Neuroendocrinology 6 235-246.

Wakade TD, Blank MA, Malhotra RK, Pourcho R \& Wakade AR 1991 The peptide VIP is a neurotransmitter in rat adrenal medulla: physiological role in controlling catecholamine secretion. Journal of Physiology 444 349-362.

Received 11 August 1998

Revised manuscript received 8 October 1998 Accepted 3 November 1998 